\title{
Injectable Contraceptive Sales at Licensed Chemical Seller Shops in Ghana: Access and Reported Use in Rural And Periurban Communities
}

\begin{abstract}
CONTEXT: Most women in Ghana obtain oral contraceptives and condoms from shops run by licensed chemical sellers, but such shops are not legally permitted to sell the country's most widely used method, the injectable. Allowing shops to sell the injectable could increase access to and use of the method.
\end{abstract}

METHODS: In 2012-2013, semistructured telephone interviews were conducted among convenience samples of 94 licensed chemical seller shop operators in two districts who were trained to sell the injectable and of 298 women who purchased the method from these shops. Follow-up interviews were conducted with 92 clients approximately three months after their initial injectable purchase.

RESULTS: Ninety-seven percent of shop operators reported selling the injectable, and $94 \%$ felt sufficiently trained to provide family planning methods and services. Virtually all sellers (99\%) referred clients to a hospital or health facility for injection; none provided injections themselves. Fifty-six percent of injectable clients were new family planning users. Of those who completed a follow-up interview, $79 \%$ had purchased the injectable again from a shop. Virtually all clients (97\%) reported getting their injection at the health facility to which they were referred by the seller. Women cited trust, convenience and commodities being in stock as key reasons for purchasing from a shop.

CONCLUSION: Licensed chemical seller shop operators can safely sell the injectable and refer clients to health facilities for screening, counseling and injection.

International Perspectives on Sexual and Reproductive Health, 2014, 40(1):21-27, doi: 10.1363/4002114

Ghana has made great progress in meeting most Millennium Development Goals; ${ }^{1}$ however, the country's reproductive health indicators continue to lag. Among married women, use of modern contraceptives is low (23\%) and unmet need for family planning remains high (26\%). ${ }^{2}$ Similarly, the total fertility rate decreased only slightly between 1998 and 2008, from 4.4 to 4. . $^{3}$ As a result, the Ghanaian government has identified increasing contraceptive prevalence as a priority. ${ }^{4}$

Among the reasons for low use of contraceptives in Ghana are barriers to access, stock-outs and a shortage of trained health staff. ${ }^{5}$ These problems are more acute in rural areas of the country, where health facilities tend to be few and the distribution chain is often weaker-conditions that contribute to an urban-rural disparity in contraceptive use and unmet need. ${ }^{3}$ In addition, access to communitybased family planning services is limited outside of select hard-to-reach areas where nurses have been mandated to provide family planning as part of the Community-Based Health Planning and Services (CHPS) model. CHPS zones are currently being scaled up, but as of 2011 , only $22 \%$ of the population was being served under CHPS. ${ }^{6}$

In many countries, private-sector drug shops are the first place people seek health care, especially in areas with few health facilities or pharmacies. ${ }^{7-10}$ In Ghana, such shops are called licensed chemical sellers and are independent businesses operated by nonpharmacists who have a minimum of a secondary education and are licensed by the Pharmacy Council to sell some over-the-counter medicines. Shop operators sometimes receive training from the Licensed Chemical Seller Association and Pharmacy Council, but it is not required to obtain a license.

As privately owned enterprises, licensed chemical seller shops are positioned to provide socially marketed family planning methods using their existing infrastructure, which is sustained by the sale of other health products. Most pill and condom users in Ghana (75\% and 54\%, respectively) receive their contraceptives from such shops; however, the country's most popular method-the threemonth injectable contraceptive, depot medroxyprogesterone acetate or DMPA-is a prescription drug and is available only from a qualified medical provider or for purchase, but not injection, from a pharmacy. ${ }^{3}$ Most injectable users $(87 \%)$ rely on public-sector health facilities to receive their injections, even though these facilities often experience stock-outs of the method.

Licensed chemical seller shops offer several advantages as a delivery channel for contraceptive commodities and services. Such shops are more numerous and thus more accessible than pharmacies: The 9,210 registered licensed chemical seller shops outnumber pharmacies five to one nationwide and as much as 25 to one in less developed regions. ${ }^{11}$ Compared with public health facilities, licensed chemical seller shops keep longer hours, have shorter wait
By Elena Lebetkin, Tracy Orr, Kafui Dzasi, Emily Keyes, Victoria Shelus, Stephen Mensah, Henry Nagai and John Stanback

Elena Lebetkin is senior technical officer, Tracy Orr is technical officer, Emily Keyes is research associate II, Victoria Shelus is research fellow and John Stanback is deputy director of the PROGRESS Project-all with FHI 360, Durham, North Carolina, USA. Kafui Dzasi is research associate, Stephen Mensah is program officer and Henry Nagai is country director-all with FHI 360, Accra Ghana. 


\begin{tabular}{|c|c|c|c|}
\hline Characteristic & $\begin{array}{l}\text { All } \\
(\mathrm{N}=94)\end{array}$ & $\begin{array}{l}\text { Amansie } \\
\text { West } \\
(\mathrm{N}=65)\end{array}$ & $\begin{array}{l}\text { Ejisu- } \\
\text { Juabeng } \\
(\mathrm{N}=29)\end{array}$ \\
\hline \multicolumn{4}{|l|}{ Sex } \\
\hline Male & 90 & 94 & 83 \\
\hline Female & 10 & 6 & 17 \\
\hline \multicolumn{4}{|l|}{ Age (yrs.) } \\
\hline $20-29$ & 8 & 11 & 3 \\
\hline 30-39 & 17 & 18 & 13 \\
\hline$\geq 40$ & 74 & 71 & 83 \\
\hline \multicolumn{4}{|l|}{ Live in same community as shop } \\
\hline Yes & 90 & 91 & 90 \\
\hline No & 10 & 9 & 10 \\
\hline \multicolumn{4}{|c|}{ Highest level of education completed } \\
\hline Middle/junior secondary & 39 & 38 & 41 \\
\hline Secondary/senior secondary & 38 & 42 & 31 \\
\hline >secondary/senior secondary & 22 & 20 & 28 \\
\hline \multicolumn{4}{|l|}{ Qualifications/credentials } \\
\hline Licensure only & 75 & 71 & 83 \\
\hline $\begin{array}{l}\text { Licensure and community health } \\
\text { worker }\end{array}$ & 12 & 15 & 3 \\
\hline Licensure and health assistant & 12 & 11 & 14 \\
\hline Licensure and nurse & 1 & 2 & 0 \\
\hline Licensure and Red Cross certificate & 1 & 2 & 0 \\
\hline Total & 100 & 100 & 100 \\
\hline
\end{tabular}

times, have staff whom clients perceive as friendlier and are less likely to suffer from stock-outs. ${ }^{8}$ Such shops are already the primary provider of oral contraceptives. Moreover, shop operators have proved capable of safely providing prescription medications with training. As part of the Mobilized Against Malaria (MAM) project in Ghana's Ashanti region, shop operators were trained to dose and administer prescription antimalarial drugs (artemisininbased combination therapies or ACTs), and to recognize and refer complicated malaria cases and suspected malaria cases in pregnant women to the nearest health facility. This program has been successful in increasing use of ACTs and appropriate referral of malaria cases. ${ }^{12}$

In 2012, FHI 360-with support from Ghana Health Services and the Pharmacy Council-implemented an intervention in two districts in the Ashanti region in which a sample of licensed chemical seller shop operators were trained to stock and sell the injectable, and to refer women to a qualified health care provider for counseling, screening for medical eligibility and injection. The objectives of this study were to determine the feasibility and acceptability of these shops' selling of the injectable from the perspective of shop operators and their clients, and to examine whether the sale of the injectable in shops was associated with increased access to and reported use of the method.

\section{METHODS}

\section{Intervention}

All licensed chemical seller shop operators trained under the MAM program in the Amansie West and Ejisu-Juabeng districts were invited to participate in this study. Aman- sie West is forested and rich in natural resources, with a population $96 \%$ rural that relies on agriculture as its main source of income; ${ }^{13}$ Ejisu-Juabeng is semiforested and predominantly agricultural, with five large urban centers that account for $30 \%$ of the population. ${ }^{14}$ The two districts were selected to represent typically rural and periurban districts, respectively.

Of the 144 MAM trained sellers, 104 (75 from Amansie West and 29 from Ejisu-Juabeng) chose to participate and received two hours of training in basic family planning, with more detailed information about the injectable; referring clients to a public health facility for injection; recording service statistics; and collecting client contact information. From May 29 to June 5, 2012, one public-sector nurse with family planning training experience in each of the two study districts was enlisted to conduct participatorystyle training for groups of 15-25 sellers in the local language, Twi. Key stakeholders from the licensed chemical seller association and directors of district health services in both districts attended and spoke at the trainings to demonstrate their support for the study, emphasize the importance of the sellers' compliance with regulations prohibiting injection of DMPA, and explain the potential contribution sellers could make to increasing access to contraceptive methods at the community level in these districts.

In addition, representatives of a local pharmaceutical company visited the training site, provided sellers with marketing support and a sample demonstration of the injectable, and sold the product to them for 30 pesewas (about US\$0.13) per vial, to be resold for 50 pesewas (about US\$0.21). Most sellers bought one box of 25 vials, and the remainder arranged to purchase the product from the company at a later date. Following the brief training on how to sell the injectable, approximately half of the licensed chemical seller shop operators (39 in Amansie West and 15 in Ejisu-Juabeng) were randomly selected to receive additional training on enrolling up to 10 clients each in the study.

The intervention was advertised to the community via local community information center announcements that aired eight times a week for the duration of the study. Advertisements gave basic information about family planning and more detailed information about the injectable; alerted the public that the injectable was being sold in licensed chemical seller shops; stated the price of the injectable; and informed people that shops would not perform injections, but were referring clients to a health facility.

\section{Study Design and Sample}

For our postintervention descriptive study, we used crosssectional and longitudinal data collected between June 2012 and January 2013 by trained interviewers via structured telephone survey with licensed chemical seller shop operators and their injectable clients; interviews were conducted in the language of the interviewees' choice, either English or Twi. After shops began selling the injectable, sellers were contacted biweekly to determine client load and 
obtain client contact information. Three months after baseline, sellers were telephoned for an interview. Interviewers made up to five attempts to reach each seller to complete an interview, after which the seller was considered lost to follow-up. Interview questions covered demographics, contraceptive method sales experience, knowledge of and attitudes toward family planning, and satisfaction with injectable sales. Ninety percent of the trained sellers were reached for interview, for an analytic sample of 94 (65 in Amansie West and 29 in Ejisu-Juabeng).

Initial client interviews were conducted with all eligible injectable clients 2-4 weeks after their first purchase of the method from a licensed chemical seller shop, to allow them time to go to a health facility and receive the injection. Shop operators collected contact information of clients who agreed to participate in the study and shared this information biweekly with interviewers. Clients were eligible for interview if they were aged 18-49 and had access to a mobile telephone. Interviewers called clients up to five times to complete the survey; those not reached were considered lost to follow-up. Survey questions covered demographics, use of family planning, acceptability and accessibility of services, and satisfaction with services received. Clients also responded to open-ended questions about their reasons for purchasing the injectable at a licensed chemical seller shop rather than at a health facility. As compensation, participating clients received two cedis (about US\$0.86)* of mobile telephone airtime.

Clients who purchased the injectable during the first three months of the study (June-August 2012) and who participated in an initial interview were called for a followup interview approximately three months after their first purchase to see if they had done so again; clients who first bought the injectable later were ineligible for a follow-up interview because of the study timeline. Follow-up interview questions focused on method continuation, location of follow-up services and satisfaction with services. Clients who completed the follow-up interview received an additional two cedis of mobile telephone airtime.

Some 298 injectable clients completed an initial interview (237 in Amansie West and 61 in Ejisu-Juabeng). Of those, 49\% (115 in Amansie West and 32 in Ejisu-Juabeng) were eligible to participate in the follow-up interview; 63\% of those eligible completed a follow-up interview (78 in Amansie West and 14 in Ejisu-Juabeng). The study was approved by the Protection of Human Subjects Committee of FHI 360 and Ghana Health Services Health and Research Development Division.

\section{Data Analysis}

Data were entered by clerks at the FHI 360 Accra office. Data cleaning took place there and at the FHI 360 headquarters in North Carolina, USA. Descriptive analyses were conducted by FHI 360 North Carolina staff using STATA 10 and SAS 9.3. All descriptive analyses were summarized using frequencies and percentages, or means and ranges as appropriate.
TABLE 2. Selected measures of contraceptive method sales and services reported by licensed chemical seller shop operators, according to district

\begin{tabular}{|c|c|c|c|}
\hline Variable & $\begin{array}{l}\text { All } \\
(N=94)\end{array}$ & $\begin{array}{l}\text { Amansie West } \\
(\mathrm{N}=65)\end{array}$ & $\begin{array}{l}\text { Ejisu-Juabeng } \\
(\mathrm{N}=29)\end{array}$ \\
\hline \multicolumn{4}{|l|}{$\%$ selling contraceptive method* } \\
\hline Injectable & 97 & 99 & 93 \\
\hline Condom & 82 & 75 & 97 \\
\hline Pills (3-pack) & 95 & 97 & 90 \\
\hline IUD & 1 & 0 & 4 \\
\hline \multicolumn{4}{|l|}{$\%$ who sold injectable prior to } \\
\hline \multicolumn{4}{|c|}{ Mean no. of methods sold per week (range) } \\
\hline Injectable & $2(0-22)$ & $2(0-22)$ & $2(0-8)$ \\
\hline Condom $\neq$ & $16(0-125)$ & $15(0-125)$ & $19(0-100)$ \\
\hline Pills (3-pack) & $8(0-40)$ & $7(0-30)$ & $10(0-40)$ \\
\hline \multicolumn{4}{|c|}{ Mean costs per method in US\$ (range) } \\
\hline Injectable & $\$ 0.21(\$ 0-0.22)$ & $\$ 0.21(\$ 0-0.22)$ & $\$ 0.22(\$ 0.02-0.22)$ \\
\hline Condom & $\$ 0.19(\$ 0-0.43)$ & $\$ 0.19(\$ 0-0.43)$ & $\$ 0.17(\$ 0.02-0.43)$ \\
\hline Pills (3-pack) & $\$ 0.27(\$ 0-1.04)$ & $\$ 0.30(\$ 0-1.04)$ & $\$ 0.21(\$ 0-0.35)$ \\
\hline$\%$ who ever injected DMPA at shop & 0 & 0 & 0 \\
\hline \multicolumn{4}{|c|}{$\%$ who referred clients to injection provider site } \\
\hline Hospital§ & 93 & 91 & 97 \\
\hline Health center & 6 & 8 & 4 \\
\hline \multicolumn{4}{|l|}{ Nurse/midwife in } \\
\hline community & 1 & 2 & 0 \\
\hline
\end{tabular}

*Multiple responses allowed. †One response missing in Amansie West. $¥$ The responses of eight shop operators were excluded because they were unreasonably high, perhaps because they gave the price per pack of 3-4 condoms, rather than the individual price. §Sellers and clients commonly referred to all health facilities as "hospitals." Notes: DMPA=depot medroxyprogesterone acetate. US\$1.00=2.33cedis.

\section{RESULTS}

\section{Licensed Chemical Seller Shop Operators}

- Demographic characteristics. Overall, the vast majority of our sample of licensed chemical seller shop operators were male (90\%), and three-quarters were 40 or older (Table 1); on average, sellers were aged 48. Ninety percent reported that they lived in the community in which their shop was located. All of the sellers had attended at least middle school (junior secondary school), and 22\% had received some postsecondary education. All had the licensure issued by the Pharmacy Council to operate a licensed chemical seller shop, and 26\% had additional qualifications, such as being a community health worker, health assistant or nurse.

- Contraceptive knowledge. A high proportion of sellers reported awareness of specific contraceptive methods (not shown), especially the injectable (96\%), condoms (93\%) and the pill (92\%). Only one operator was unable to correctly state the length of effectiveness of the injectable. Sellers gave various answers as to common side effects of the injectable, but those mentioned by the greatest proportion of sellers were irregular menses (70\%), followed by headache (62\%) and weight gain (50\%).

- Contraceptive sales and referrals. Sixty-four percent of the shop operators (57\% in Amansie West and 79\% in Ejisu-Juabeng) reported an increase in the volume of family planning clients during the intervention. Ninety-seven percent reported selling the injectable, $95 \%$ oral contra-

*US\$1.00 $=2.33$ cedis 
TABLE 3. Percentage distribution of women who purchased the injectable from shops operated by trained, licensed chemical sellers, by district and interview, according to selected characteristics

\begin{tabular}{|c|c|c|c|c|}
\hline \multirow[t]{2}{*}{ Characteristic } & \multicolumn{3}{|l|}{ Baseline } & \multirow{2}{*}{$\begin{array}{l}\text { Follow-up } \\
\text { All } \\
(\mathrm{N}=92)\end{array}$} \\
\hline & $\begin{array}{l}\text { All } \\
(\mathrm{N}=298)\end{array}$ & $\begin{array}{l}\text { Amansie } \\
\text { West } \\
(\mathrm{N}=237)\end{array}$ & $\begin{array}{l}\text { Ejisu- } \\
\text { Juabeng } \\
(\mathrm{N}=61)\end{array}$ & \\
\hline \multicolumn{5}{|l|}{ Age } \\
\hline$<20$ & 9 & 9 & 8 & 13 \\
\hline $20-29$ & 60 & 60 & 57 & 58 \\
\hline 30-39 & 25 & 25 & 27 & 22 \\
\hline$\geq 40$ & 6 & 6 & 7 & 8 \\
\hline \multicolumn{5}{|l|}{ Partnership status } \\
\hline Married & 60 & 58 & 64 & 58 \\
\hline Boyfriend/regular sexual partner & 32 & 33 & 25 & 41 \\
\hline Other & 9 & 8 & 12 & 1 \\
\hline \multicolumn{5}{|l|}{ Highest level of education completed } \\
\hline None & 14 & 14 & 13 & 15 \\
\hline Primary & 23 & 23 & 23 & 28 \\
\hline Middle/junior secondary & 52 & 52 & 52 & 39 \\
\hline Secondary/senior secondary & 10 & 9 & 11 & 15 \\
\hline >secondary/senior secondary & 1 & 1 & 0 & 2 \\
\hline \multicolumn{5}{|l|}{ No. of living children* } \\
\hline 0 & 20 & 22 & 14 & 24 \\
\hline $1-3$ & 56 & 54 & 66 & 56 \\
\hline$\geq 4$ & 24 & 23 & 21 & 21 \\
\hline \multicolumn{5}{|l|}{ Desire for child/additional childrent } \\
\hline Yes & 34 & 28 & 17 & 55 \\
\hline No & 29 & 38 & 34 & 25 \\
\hline Undecided/depends & 37 & 34 & 49 & 20 \\
\hline \multicolumn{5}{|l|}{ Ever used family planning¥ } \\
\hline Yes & 44 & 42 & 54 & na \\
\hline No & 56 & 58 & 46 & na \\
\hline \multicolumn{5}{|l|}{ Method used in last 3 mos.§ } \\
\hline None & 11 & 10 & 12 & na \\
\hline Injectable (continuing user) & 28 & 34 & 12 & na \\
\hline Condom & 2 & 2 & 0 & na \\
\hline Pills & 45 & 43 & 52 & na \\
\hline Implant & 3 & 3 & 3 & na \\
\hline Dual method (pills and condoms)** & 11 & 8 & 21 & na \\
\hline Total & 100 & 100 & 100 & 100 \\
\hline
\end{tabular}

*One person did not respond and was excluded from initial interview. $†$ Three people did not respond and were excluded from initial interview. $\neq$ One person did not respond and was excluded. §Among those who reported ever use of family planning. ${ }^{* *}$ One person reported dual use of the injectable and condoms, and was considered an injectable user. Note: na=not applicable.

ceptive pills and $82 \%$ condoms (Table 2, page 23); however, this varied by district. For example, $1 \%$ of trained sellers in Amansie West and 7\% in Ejisu-Juabeng reported not selling the injectable, despite having participated in the training and purchased the method for resale. Four percent of sellers overall-6\% in Amansie West and 0\% in Ejisu-Juabeng-had sold the injectable prior to the study. On average, operators reported selling two vials of the injectable per week; they sold 16 individual condoms and eight three-packs of oral contraceptives.

The sale price of the injectable reported by sellers varied from US\$0 to US $\$ 0.22$ (0-0.50 cedis), which was the

*Study staff reported that licensed chemical sellers and clients commonly referred to all health facilities as "hospitals." agreed price range for the term of the study; the mean price was US\$0.21 (0.49 cedis). Condoms-generally sold either individually or in packs of three or four-ranged in price from US\$0 to US\$0.43 (0-1.00 cedis) each, with an average price of US\$0.19 (0.43 cedis) per condom. Oral contraceptive pills-sold in packs of three cycles-ranged from US $\$ 0$ to US\$1.04 ( $0-2.40$ cedis), with an average price of US $\$ 0.27$ (0.63 cedis). We are unsure why some sellers reported giving away contraceptive methods, but believe based on anecdotal evidence that they may be providing methods free of cost to friends or family at times.

No sellers reported giving clients DMPA injections in their shop. In most cases (93\%), shop operators referred clients to a hospital;* $6 \%$ referred to a health center, and $1 \%$ to a nurse or midwife living in the community. Nearly all sellers (94\%) reported feeling that they received the training needed to provide clients with the contraceptives and family planning services that the clients wanted (not shown); however, they reported several challenges related to selling the injectable, including the inability to inject the drug and client misconceptions about the method. The top two ideas the sellers had to improve their injectable sales training were to train them to inject the drug and to better advertise the product.

\section{Injectable Clients of Licensed Chemical Seller Shops}

- Demographic characteristics and contraceptive history. Of our sample of women who purchased the injectable at licensed chemical seller shops, 69\% were younger than 30 at baseline (Table 3); the average age of the baseline sample was 27 years (not shown). Sixty percent of women were married, and $32 \%$ had a boyfriend or regular sexual partner. Most reported having some formal education (86\%) and at least one living child (80\%); on average, women had 2.2 living children (not shown). One-third of injectable clients reported having the desire to have a child or more children, 29\% did not want a child or more children, and $37 \%$ were unsure or fatalistic about the decision.

Many of the injectable clients interviewed were new family planning users. Overall, 56\% reported never having used family planning before their injectable purchase; that proportion was 58\% in Amansie West and 46\% in EjisuJuabeng. Among those who had ever used family planning, $89 \%$ reported using a method within the last three months. The greatest proportion (45\%) were switching to the injectable from the pill (45\%) or were continuing injectable users (28\%). In Amansie West, 34\% of women with contraceptive experience were continuing injectable users, and $8 \%$ reported dual use of the pill with condoms; in Ejisu-Juabeng, only 12\% were continuing injectable users, and 21\% were using the pill with condoms.

Of the 92 injectable clients who completed a follow-up interview, 79\% had purchased the method again from a licensed chemical seller. Among those who had not, most were no longer using family planning, but a few were getting the injectable from a different source.

-Access to and cost of the injectable. All women who pur- 
chased DMPA from a licensed chemical seller shop had the method injected (Table 4); local hospitals were the most common site for injection (69\%), followed by a health center (26\%). No women reported having their injection performed at a licensed chemical seller shop. Virtually all women $(97 \%)$ went to the provider site they were referred to by the licensed chemical seller (not shown).

On average, women reported traveling $1.6 \mathrm{~km}$ or 21 minutes from their home to the shop from which they purchased the injectable; three-quarters of women walked to the shop, and 21\% took commercial transportation (not shown). The average distance women traveled to receive their DMPA injection was $3.1 \mathrm{~km}$ and their average travel time was 28 minutes.

The mean total cost to clients of using the injectableincluding the amounts paid for the method, its injection and associated transportation-was US $\$ 1.18$ (2.72 cedisTable 5); the range was US\$0-5.84 (0-13.50 cedis). The most expensive single component was the fee provider sites charged for the injection (mean, US\$0.56 or 1.30 cedis), followed by the cost of transportation to the injection provider site (US $\$ 0.27$ or 0.63 cedis). On average, women in Ejisu-Juabeng reported paying US $\$ 1.38$ (3.19 cedis), whereas women in Amansie West paid US\$1.12 (2.59 cedis). The majority of women perceived the total cost as acceptable (not shown).

- Reasons for purchasing the injectable. Women reported that they had purchased the injectable mainly because they did not want more children (29\%), their husband or partner wanted them to use the method (25\%), or it was recommended by a friend, relative or licensed chemical seller (17\%). Convenience of the location (29\%), as well as trust and comfort with the seller (22\%), were the reasons women most commonly reported for purchasing the injectable at a licensed chemical seller shop and for choosing a shop over a health facility. In addition, one-third of women reported the good price and 16\% the method being in stock as reasons for purchasing from a shop rather than a health facility. One-third of women reported that they purchased the injectable at a shop because they had heard the community information center advertisement. When women were asked if they knew of anywhere other than
TABLE 4. Select measures of injectable clients of licensed chemical seller shops, according to district

\begin{tabular}{|c|c|c|c|}
\hline Variable & $\begin{array}{l}\text { All } \\
(\mathrm{N}=298)\end{array}$ & $\begin{array}{l}\text { Amansie West } \\
(\mathrm{N}=237)\end{array}$ & $\begin{array}{l}\text { Ejisu-Juabeng } \\
(\mathrm{N}=61)\end{array}$ \\
\hline$\%$ who received DMPA injection & 100 & 100 & 100 \\
\hline \multicolumn{4}{|c|}{$\%$ who received injection at provider site } \\
\hline Licensed chemical seller shop & 0 & 0 & 0 \\
\hline Hospital & 69 & 69 & 67 \\
\hline Health center & 26 & 26 & 26 \\
\hline Health post/CHPS & 1 & 1 & 3 \\
\hline Unknown & 1 & 2 & 0 \\
\hline Other private facility* & 2 & 2 & 3 \\
\hline \multicolumn{4}{|l|}{ From home to shop } \\
\hline Mean distance in km (range)† & $1.6(0.5-11.3)$ & $1.6(0.5-11.3)$ & $1.3(0.5-6.4)$ \\
\hline Mean time in minutes (range)‡ & $21(0-180)$ & $21(0-180)$ & $21(1-120)$ \\
\hline \multicolumn{4}{|l|}{ From home to injection site } \\
\hline Mean distance in km (range)§ & $3.1(0.5-56)$ & $2.9(0.5-30)$ & $3.8(0.5-56)$ \\
\hline Mean time in minutes (range) ${ }^{* *}$ & $28.1(0-180)$ & $29.8(0-180)$ & $22.4(0-90)$ \\
\hline
\end{tabular}

*Includes family planning clinics, maternity homes and polyclinics. +98 women (74 in Amansie West and 24 in Ejisu-Juabeng) did not respond and were excluded. $\$ 91$ women (71 in Amansie West and 20 in Ejisu-Juabeng) did not respond and were excluded. $\$ 111$ women (85 in Amansie West and 26 in EjisuJuabeng) did not respond and were excluded. ${ }^{* *}$ Four women did not respond and were excluded. Notes: DMPA=depot medroxyprogesterone acetate. CHPS=community-based health planning and services. km=kilometers.

a shop to purchase the injectable, $70 \%$ could not report another location and 22\% reported the hospital. Among women who could name another place from which to purchase the method, distance (34\%), stock-outs (22\%) and cost $(20 \%)$ were the top three reasons for not going there. - Knowledge of side effects and complications. Virtually all of the clients (99\%) were able to correctly state the length of effectiveness of the injectable. They had poor knowledge, however, of side effects and complications associated with the method: Only 45\% were able to spontaneously mention at least one side effect, and 32\% were able to spontaneously mention a complication. The most commonly mentioned side effect was amenorrhea or bleeding irregularities (35\%), and the most commonly mentioned complication was severe headache (20\%). Knowledge varied little by the type of facility in which the client received the injection.

- Acceptability of and satisfaction with shop. Clients uniformly (99\%) reported satisfaction with their shop visit. The vast majority stated that the shop operator was able

\begin{tabular}{|c|c|c|c|c|c|c|}
\hline \multirow[t]{2}{*}{ Cost (in US\$) } & \multicolumn{2}{|c|}{$\begin{array}{l}\text { All } \\
(\mathrm{N}=298)\end{array}$} & \multicolumn{2}{|c|}{$\begin{array}{l}\text { Amansie West } \\
(\mathrm{N}=237)\end{array}$} & \multicolumn{2}{|c|}{$\begin{array}{l}\text { Ejisu-Juabeng } \\
(\mathrm{N}=61)\end{array}$} \\
\hline & Mean & Range & Mean & Range & Mean & Range \\
\hline Transportation to seller shop* & 0.09 & $0-1.73$ & 0.09 & $0-1.73$ & 0.08 & $0-1.30$ \\
\hline Method + & 0.26 & $0-2.16$ & 0.27 & $0-2.16$ & 0.25 & $0-2.16$ \\
\hline Transportation to injection provider siteł & 0.27 & $0-2.16$ & 0.26 & $0-2.16$ & 0.32 & $0-2.16$ \\
\hline Injection§ & 0.56 & $0-2.16$ & 0.52 & $0-2.16$ & 0.69 & $0-2.16$ \\
\hline Total ${ }^{* *}$ & 1.18 & $0-5.84$ & 1.12 & $0-5.84$ & 1.38 & $0.22-5.84$ \\
\hline
\end{tabular}

*Three women did not respond and were excluded. †One woman did not respond and was excluded. $¥$ Four women did not respond and were excluded. §Two women were excluded: One did not respond and the other was an extreme outlier. ${ }^{* *}$ Ten women were excluded: nine because they did not respond to one of the items included in the total, and one because she was an extreme outlier. Notes: Subpopulation means (e.g., transportation, method) were calculated on the basis of the number of people who responded to that question regardless whether they answered any of the other questions; total means only included people who answered all four subpopulation questions, so the dominators are slightly different in the computation of each mean. US\$1.00=2.33cedis. 
to provide the products and services needed (96\%) and that they would purchase the injectable from a shop again (93\%). Clients consistently stated that they trusted the seller and that the seller was able to take the time to answer questions and to explain the injectable, as well as pregnancy prevention in general. The consistency of the supply and the low price of the injectable at the shop were also among the most common reasons for satisfaction mentioned by clients. Advertising, allowing the sellers to inject DMPA and keeping the price of the method low were the most frequent suggestions for improving services at licensed chemical seller shops.

\section{DISCUSSION}

One previous program provided evidence that licensed chemical sellers in Ghana are able to sell prescription medication; ${ }^{12}$ however, the study presented here was the first in Ghana to examine the acceptability and safety of selling prescription contraceptive methods in shops. The intervention to train licensed chemical seller shop operators to sell the injectable showed benefits for both sellers and clients. Nearly all trained operators sold the method and referred clients to health facilities for counseling and safe injection, and more than half reported an increase in their volume of family planning clients. As for clients, all women who purchased the injectable from a shop received a DMPA injection, and satisfaction with sellers was high. No cases of a seller giving a client a DMPA injection were reported by sellers or clients.

In Ghana, licensed chemical seller shops already play an important role in meeting the family planning needs of women. Most sellers live where their shop is located, are respected members of that community and are considered first-line medical providers there. ${ }^{15}$ Women feel comfortable talking to a licensed chemical seller about their family planning needs, and trust and respect his or her advice. ${ }^{8}$

However, women seek services from licensed chemical sellers not only because of trust, but also for convenience and accessibility. Shops are ubiquitous in the countryeven in rural areas-and far outnumber health facilities. ${ }^{16}$ Distance to a health facility is a well-documented barrier to receiving family planning services and commodities. ${ }^{17}$ And that barrier is compounded by the potential of traveling to a health facility, only to be turned away because of a commodity stock-out. In Ghana, stock-outs of the injectable are common in the public sector, ${ }^{18}$ but because shops are private-sector businesses, they are better poised to keep a continuous supply of products. ${ }^{15}$ And although the intervention described in this article does require women to travel to a shop to purchase the injectable and then to a health facility to receive the injection, they arrive at the health facility with the method in hand, confident that they will not be turned away because of a stock-out.

As a result of this study, Ghana Health Services and the Pharmacy Council are reviewing policies on licensed chemical sellers' sale of the injectable and are planning to change the policy to allow licensed chemical sellers to continue selling the method in the study districts. Also, they have committed to developing a plan for a targeted national scale-up of this practice.

\section{Limitations}

This study has three key limitations. First, we relied on clients' self-report in regard to their receiving the DMPA injection at a health facility instead of verifying it with the health facility. Clients' reports of receiving the injection at the health facility, however, concur with the sellers' reports of selling the injectable to clients and of referring them to the health facility. Despite the consistent client and seller reports, social desirability bias may have had an impact on the reporting of the location of the injection, as both clients and sellers were made aware that injection of the method anywhere besides the health facility was not permitted. Second, data collection occurred via mobile telephone and, therefore, women without access to a mobile telephonewho may represent a lower socioeconomic group or a more rural population than women with access to a mobile phone-were excluded. Finally, 37\% of the eligible women were lost to follow up, and those women may have differed from the women who completed a follow-up interview. According to our data, however, the women who participated in the follow-up interview were demographically similar to those who participated in the initial interview.

\section{CONCLUSION}

With little technical input, the licensed chemical sellers' sale of DMPA could be scaled up to cover the entire country. Making the injectable available at every licensed chemical seller shop in Ghana would dramatically increase women's access-especially in rural areas-to this popular contraceptive method, and would be beneficial to women, sellers and Ghana Health Services.

Future research on training licensed chemical sellers to provide DMPA injections as community health workers should be considered in Ghana, as the provision of the injectable at the community level by minimally trained community health workers has been shown to be safe and effective in settings in Africa and elsewhere, and is currently being scaled up in many countries. ${ }^{19-21}$

\section{REFERENCES}

1. United Nations Development Programme (UNDP) and Ghana National Development Planning Commission, 2010 Ghana Millennium Development Goals Report, Accra, Ghana: UNDP, 2012, <http://www. ndpc.gov.gh/GPRS/2010\%20Ghana's\%20MDGs\%20Report\%20 (Final)\%20-\%20Nov2012.pdf>, accessed Feb. 24, 2014

2. Ghana Statistical Service (GSS), Ghana Multiple Indicator Cluster Survey with an Enhanced Malaria Module and Biomarker, 2011, Accra, Ghana: GSS, 2012

3. GSS, Ghana Health Service and ICF Macro, Ghana Demographic and Health Survey 2008, Accra, Ghana: GSS, Ghana Health Service and ICF Macro, 2009.

4. Ghana National Development Family Planning Commission, Medium-Term National Development Policy Framework: Ghana Shared Growth and Development Agenda (2010-2013), Washington, DC: International Monetary Fund, 2010.

5. Ghana Health Services (GHS), Reproductive Health Strategic Plan 
2007-2011, Accra, Ghana: GHS, 2007.

6. Ghana Health Service, Ghana Health Services Annual Report 2011, Accra, Ghana: Ghana Health Service, 2011.

7. Sudhinaraset $\mathrm{M}$ et al., What is the role of informal healthcare providers in developing countries? A systematic review, PLoS ONE, 2013, 8(2):e54978.

8. Brieger WR et al., Interactions between patent medicine vendors and customers in urban and rural Nigeria, Health Policy and Planning, 2004, 19(3):177-182

9. Stanback J et al., Injected with controversy: sales and administration of injectable contraceptives in drug shops in Uganda, International Perspectives on Sexual and Reproductive Health, 2011, 37(1):24-29.

10. Goodman C et al., Medicine sellers and malaria treatment in SubSaharan Africa: what do they do and how can their practice be improved? American Journal of Tropical Medicine and Hygiene, 2007, 77(6, Suppl):203-218.

11. Ghana Pharmacy Council, MIS/Publications Unit, Collated Data, Accra, Ghana: Ghana Pharmacy Council, 2012.

12. Pfizer MAM, Lessons Learned from Ghana, New York: Pfizer, 2010.

13. Ghana Ministry of Food and Agriculture, Amansie West, 2013, <http://mofa.gov.gh/site/?page_id=837>, accessed Dec. 12, 2013

14. Ghana Ministry of Food and Agriculture, Ejisu-Juabeng, 2013, <http://mofa.gov.gh/site/?page_id=855>, accessed Dec. 11, 2013.

15. Wafula FN, Miriti EM and Goodman CA, Examining characteristics, knowledge and regulatory practices of specialized drug shops in Sub-Saharan Africa: a systematic review of the literature, BMC Health Services Research, 2012, 12(7):223.

16. Ghana Ministry of Health, World Health Organization and Department for International Development, Service Availability Mapping (SAM), Accra, Ghana: Ministry of Health, 2007.

17. Bertrand JT et al., Access, quality of care and medical barriers in family planning programs, International Family Planning Perspectives, 1995, 21(2):64-69.

18. U.S. Agency for International Development (USAID), Task Order 4 Annual Report: October 2011-September 2012, Arlington, VA: USAID, 2012.

19. Malarcher S et al., Provision of DMPA by community health workers: what the evidence shows, Contraception, 2011, 83(6):495-503.

20. Hoke $\mathrm{T}$ et al., Community-based distribution of injectable contraceptives: introduction strategies in four Sub-Saharan African countries, International Perspectives on Sexual and Reproductive Health, 2012, 38(4):214-219

21. Stanback J et al., Community-based health workers can safely and effectively administer injectable contraceptives: conclusions from a technical consultation, Contraception, 2010, 81(3):181-184

\section{RESUMEN}

Contexto: La mayoría de las mujeres en Ghana obtienen anticonceptivos orales y condones en comercios administrados por vendedores autorizados de productos químicos. Sin embargo, esos comercios no tienen permiso para vender legalmente el método anticonceptivo más ampliamente usado en el país, el inyectable. Permitir a los comercios la venta del inyectable podría aumentar el acceso al método y su uso.

Métodos: En el período 2012-2013, se condujeron entrevistas telefónicas semiestructuradas en muestras por conveniencia de 94 operadores autorizados para la venta de productos químicos en dos distritos, que habían sido capacitados para vender el método inyectable, y de 298 mujeres que compraron el método en esos comercios. Aproximadamente tres meses después de la primera compra del inyectable, se condujeron entrevistas de seguimiento con 92 clientas.
Resultados: El noventa y siete por ciento de los operadores de los comercios reportaron ventas del inyectable, y el 94\% se sintió suficientemente capacitado para proveer métodos y servicios de planificación familiar. Prácticamente todos los vendedores (el 99\%) refirieron a sus clientas a un hospital o institución de salud para recibir la inyección; ninguno proveyó la inyección directamente. El cincuenta y seis por ciento de las clientas de inyectables eran nuevas usuarias de planificación familiar., El 79\% de las mujeres que completaron la entrevista de seguimiento volvieron a comprar el inyectable en un comercio. Prácticamente todas las clientas (el 97\%) reportaron haber recibido la inyección en la institución de salud a la que fueron referidas por el vendedor. Las mujeres citaron la confianza, la conveniencia y la disponibilidad del producto en stock como las razones principales para comprarlo en una tienda.

Conclusión: Los comercios administrados por vendedores autorizados de productos químicos pueden vender el inyectable y referir a las clientas a instituciones de salud para revisiones, consejería y la provisión de inyecciones.

\section{RÉSUMÉ}

Contexte: La plupart des Ghanéennes obtiennent leur contraception orale et le préservatif dans des points de vente parapharmaceutiques autorisés, que la loi ne permit cependant pas à vendre la méthode la plus pratiquée dans le pays, l'injectable. L'autorisation de cette vente pourrait améliorer l'accès à la méthode et sa pratique. Méthodes: En 2012-2013, des interviews téléphoniques semi-structurées ont été menées auprès d'échantillons de commodité de 94 exploitants de point de vente autorisés formés à la vente de l'injectable dans deux districts, ainsi que de 298 acheteuses de la méthode auprès de ces exploitants. Des entretiens de suivi ont été menés auprès de 92 clientes environ trois mois après leur achat initial de l'injectable.

Résultats: Quatre-vingt-dix-sept pour cent des exploitants ont déclaré vendre l'injectable et 94\% s'estimaient suffisamment formés à l'offre de méthodes et services de planification familiale. Pratiquement tous les vendeurs (99\%) avaient orienté leurs clientes vers un hôpital ou une structure de santé pour l'injection; aucun n'avait effectué lui-même l'injection. Cinquante-six pour cent des clientes acheteuses de l'injectable étaient de nouvelles utilisatrices de la planification familiale. De celles ayant participé à l'interview de suivi, 79\% avaient répété leur achat de l'injectable dans un point de vente autorisé. Pratiquement toutes les clientes (97\%) ont déclaré s'être adressées, pour l'injection, au centre de santé recommandé par le vendeur. Les femmes ont cité la confiance, la commodité et la disponibilité immédiate des produits comme raisons principales de leurs achats auprès de tels vendeurs.

Conclusion: Les points de vente parapharmaceutiques autorisés peuvent vendre l'injectable sans risques et orienter leurs clientes vers les structures de santé aux fins de l'évaluation, du conseil et de l'injection.

\section{Acknowledgment}

Support for this study was provided by FHI 360 with funds from the U.S. Agency for International Development (USAID) under the PROGRESS Project (GPO-A-00-08-00001-00). The views expressed in this publication do not necessarily reflect those of FHI 360 or USAID.

Author email: elebetkin@fhi360.org 